\title{
Karakterisasi Xilanase dari Bakteri Xilanolitik XJ20 asal Tanah Hutan Taman Nasional Bukit Duabelas Jambi Indonesia
}

\author{
Characterization of Xylanase from Xylanolitic Bacteria XJ20 Isolated \\ from Forest Land Bukit Duabelas National Park Jambi Indonesia
}

\author{
MAZIDAH NOER INAYAH ${ }^{1}$, LAKSMI AMBARSARI ${ }^{2}$, ANJA MERYANDINI ${ }^{1}$
}

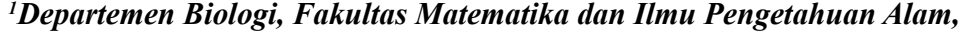 \\ Institut Pertanian Bogor, Dramaga IPB, Bogor, Jawa Barat, 16680 Indonesia \\ ${ }^{2}$ Departemen Biokimia Fakultas Matematika dan Ilmu Pengetahuan Alam, \\ Institut Pertanian Bogor, Dramaga IPB, Bogor, Jawa Barat, 16680 Indonesia
}

Diterima 14 Mei 2016/Disetujui 19 Juni 2016

\begin{abstract}
Xylanase is an extracellular enzymes that can be produced by microbes which capable to degrade xylan into xilo-oligosaccharides (XOS) and xylose. Application of xylanase is still not optimal due to the lack of availability of superior microbial cultures producing xylanase. The purpose of this study was to determine the characteristics of xylanase produced by bacteria isolated from Forest land Bukit Duabelas National Park, Jambi, Indonesia. Xylanase produced by bacterial isolate XJ20 was selected for further enzymatic activity and characteritics assays. Xylanolytic activity was measured by using the 3.5-dinitrosalicylic acid (DNS) assay. High activity of xylanase was recorded at three times of incubation, which were $6(0.015 \mathrm{U} / \mathrm{mL}), 14(0.012 \mathrm{U} / \mathrm{mL})$ and $20(0.007 \mathrm{U} / \mathrm{mL})$. The first peak and the second peak reached the highest activity at a temperature of $70^{\circ} \mathrm{C}$, however, the first peak reached the highest activity at $\mathrm{pH} 4.0$ and a second peak at $\mathrm{pH}$ 7.0. $\mathrm{pH} 4.0$ xylanase were incubated at room temperature and $70^{\circ} \mathrm{C}$ has a half time consecutive 9 hours and 6 hours, whereas at pH 7.0, has a half time consecutive 4 hours and 3 hours. Stability of enzyme better at pH 4.0 and at room temperature.
\end{abstract}

Keywords: DNS, enzymatic activity, enzyme stability, xylanase.

\section{PENDAHULUAN}

Limbah pertanian banyak mengandung lignoselulosa (hemiselulosa, selulosa, dan lignin) dan karbohidrat yang tinggi (Trismilah \& Waltam 2009). Hemiselulosa merupakan heteropolimerpolisakarida yang keberadaaannya paling melimpah kedua di alam setelah selulosa. Xilan merupakan komponen utama penyusun hemiselulosa yang memiliki tulang punggung rantai $\mathrm{D}$-xilopiranosa dengan ikatan $\beta-1,4$ glikosidik. Xilan memiliki residu $O$-asetil, arabinosil dan 4-O-metil-D- asam glukoronat yang terikat pada tulang punggungnya. Hasil hidrolisis xilan oleh xilanase adalah xilooligosakarida (XOS) dan selanjutnya menjadi monomernya yaitu xilosa, arabinosa dan asam glukoronik (Kulkarni et al. 1999). Hidrolisis lengkap xilan menjadi monomernya memerlukan kerja sinergi beberapa enzim xilanolitik (Subramaniyan \& Prema 2002).

Enzim xilanolitik merupakan enzim kompleks yang terdiri atas $1,4-\beta$-endoxilanase, $\beta$-xilosidase, $\alpha$-L-arabinofuranosidase, $\alpha$-glukuronidase, asetil xilan esterase dan asam fenolat (Yang et al. 2009). Xilanase dapat dihasilkan oleh mikroba dan memiliki

${ }^{*}$ Penulis korespondensi. Phone: $+62-8121107021$

E-mail: abdulmunif@ipb.ac.id aplikasi yang luas, misalnya dalam bidang peternakan (Richana 2002), meningkatkan aroma jus dan anggur serta likuifikasi buah dan sayur (Beg et al. 2001), sebagai agen klarifikasi dalam pembuatan wine (Viikari 2001), untuk pemutihan kertas (Wang et al. 2010), peningkatan kualitas roti (Zheng et al. 2011) serta produksi bioetanol (Samsuri et al. 2009). Namun demikian, saat ini aplikasi xilanase masih belum optimal meskipun telah banyak penelitian yang melaporkan adanya mikroba unggul penghasil xilanase. Hal tersebut disebabkan oleh kurangnya pengoptimalan potensi dari mikroba unggul penghasil xilanase.

Kami telah berhasil mengisolasi isolat bakteri xilanolitik dari tanah Hutan Taman Nasional Bukit Duabelas (TNBD) Jambi, Indonesia namun belum diteliti kemampuannya dalam menghasilkan xilanase, sehingga penelitian kemampuan isolat bakteri dalam menghasilkan xilanase dan karakterisasinya perlu untuk dilakukan.

\section{BAHAN DAN METODE}

Bahan Penelitian. Bahan yang digunakan meliputi isolat bakteri xilanolitik asal Taman Nasional Bukit Duabelas (TNBD) Jambi, koleksi Laboratorium 
Bioteknologi Hewan dan Biomedis, PPSHB, IPB; substrat xilan Beechwood (Sigma); Baktopepton; ekstrak khamir; $\mathrm{MgSO}_{4} ; \mathrm{K}_{2} \mathrm{HPO}_{4}$; agar-agar; reagen 3.5-dinitrosalicylic acid (DNS); bufer fosfat; bufer sitrat; dan bufer glisin $\mathrm{NaOH}$.

Peremajaan Isolat Bakteri Xilanolitik. Peremajaan isolat dilakukan pada media cair xilan $0.5 \%$ sebanyak $20 \mathrm{~mL}$ yang diinkubasi pada suhu ruang menggunakan inkubator bergoyang selama 24 jam. Selanjutnya sebanyak $1 \mathrm{~mL}$ kultur diambil dan ditumbuhkan kembali pada media cair xilan $0.5 \%$ dan diinkubasi kembali pada suhu ruang selama 24 jam, untuk digunakan sebagai kultur utama.

Pembuatan Kurva Tumbuh Bakteri dan Penentuan Waktu Optimum Aktivitas Xilanase. Pembuatan kurva tumbuh bakteri diawali dengan meremajakan isolat bakteri pada media cair xilan $0.5 \%$, kemudian dipindahkan pada media padat agar miring. Selanjutnya dilakukan pembuatan inokulum dengan menginokulasikan isolat ke dalam $20 \mathrm{~mL}$ media cair xilan $0.5 \%$ dan diinkubasi pada suhu ruang menggunakan inkubator bergoyang hingga densitas sel yang terukur dengan spektrofotometer pada panjang gelombang $(\lambda) 600 \mathrm{~nm}$ mencapai 0.6-0.8 A. Sebanyak $1 \mathrm{~mL}$ inokulum dikulturkan pada $100 \mathrm{~mL}$ media cair xilan $0.5 \%$ dalam Erlenmeyer $500 \mathrm{~mL}$, diinkubasi pada suhu ruang menggunakan inkubator bergoyang dan dilakukan pengukuran densitas sel setiap 2 jam dengan menggunakan spektrofotometer $(\lambda 600 \mathrm{~nm})$ untuk pembuatan kurva tumbuh.

Penentuan waktu optimum aktivitas xilanase dilakukan bersamaan dengan pembuatan kurva tumbuh dengan cara memanen kultur dalam media untuk kemudian disentrifugasi pada kecepatan $15000 \mathrm{~g}$ selama 15 menit pada suhu $4{ }^{\circ} \mathrm{C}$ setiap 2 jam untuk mendapatkan supernatan. Supernatan sebagai ekstrak enzim kasar (EEK) diukur aktivitasnya dengan menggunakan metode DNS (Miller 1959). Substrat yang digunakan untuk mengukur aktivitas enzim xilanase adalah xilan Beechwood 0.5\% dengan waktu inkubasi 30 menit. Pengukuran aktivitas enzim dihitung berdasarkan standar xilosa. Gula pereduksi yang dihasilkan diukur dengan spektrofotometer pada $\lambda 540 \mathrm{~nm}$.

Penentuan pH dan Suhu Optimum Xilanase serta Stabilitasnya. EEK yang diperoleh pada waktu produksi tertinggi diuji aktivitasnya dalam berbagai kondisi $\mathrm{pH}$ dan suhu. Uji pengaruh $\mathrm{pH}$ dilakukan pada $\mathrm{pH}$ 4.0-10 dengan interval 1.0. EEK yang diuji pada $\mathrm{pH}$ 4.0-6.0 digunakan larutan penyangga sitrat (campuran antara larutan asam sitrat dan larutan $\mathrm{Na}_{2} \mathrm{HPO}_{4}$ ), untuk $\mathrm{pH}$ 6.0-8.0 digunakan larutan penyangga fosfat (campuran larutan $\mathrm{NaH}_{2} \mathrm{PO}_{4}$ dan $\mathrm{Na}_{2} \mathrm{HPO}_{4}$ ) dan untuk $\mathrm{pH}$ 8.010.0 digunakan larutan penyangga glisin $\mathrm{NaOH}$. Uji pengaruh suhu terhadap aktivitas enzim dilakukan pada suhu $30-90^{\circ} \mathrm{C}$, dengan interval $10^{\circ} \mathrm{C}$. EEK direaksikan dengan substrat xilan yang dilarutkan dalam larutan penyangga $0.05 \mathrm{M}$. Pengukuran aktivitas xilanase pada kondisi berbagai pengaruh $\mathrm{pH}$ dan suhu dilakukan menggunakan metode DNS (Miller 1959). Uji stabilitas enzim dilakukan dengan menginkubasikan ekstrak kasar enzim pada dua suhu yang berbeda, yaitu pada suhu optimumnya, dan suhu ruang. EEK diuji setiap jam pada $\mathrm{pH}$ dan suhu optimumnya dengan substrat xilan $0.5 \%$. Pengujian dilakukan hingga enzim tidak memiliki aktivitas lagi. Daya tahan enzim diketahui dengan menghitung nilai (\%) aktivitas enzim relatif.

\section{HASIL}

Peremajaan Isolat bakteri xilanolitik. Isolat bakteri ditumbuhkan pada media padat xilan $0.5 \%$. Selanjutnya dilakukan pewarnaan Gram dan pencirian morfologi isolat. Hasil pewarnaan Gram menunjukkan bahwa isolat XJ20 merupakan bakteri Gram positifberbentuk bulat (kokus). Ciri morfolgi koloni isolat XJ20 yaitu berwarna putih kekuningan, memiliki diameter $1 \mathrm{~mm}$, elevasi cembung, tepian tidak beraturan, berbentuk L serta berbau anyir (Gambar 1).

Kurva Tumbuh Bakteri dan Waktu Optimum Aktivitas Xilanase. Isolat XJ20 memiliki tiga puncak aktivitas enzim, yaitu pada jam ke-6 $(0.015 \mathrm{U} / \mathrm{mL})$, jam ke-14 (0.012 U/mL) dan jam ke-20 $(0.007 \mathrm{U} / \mathrm{mL})$. Puncak aktivitas enzim pada jam ke-6 merupakan puncak tertinggi dimana bakteri berada dalam fase eksponensial, sedangkan aktivitas enzim pada puncak kedua dan ketiga terjadi ketika bakteri berada dalam fase stasioner (Gambar 2).

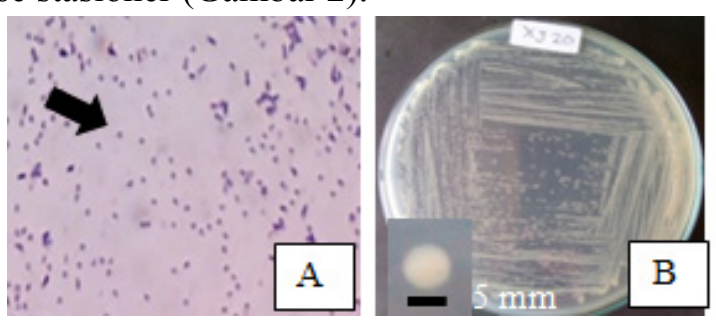

Gambar 1 Morfologi isolat bakteri XJ20. A) Pewarnaan Gram, B) Pertumbuhan isolat bakteri XJ20 berumur 24 jam, ditumbuhkan pada media padat xilan $0.5 \%$ dan diinkubasi suhu ruang.

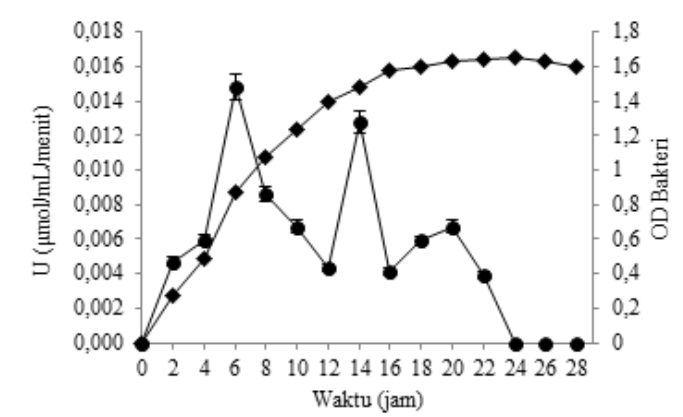

Gambar 2 Aktivitas enzim xilanase $(\bullet)$ dan pertumbuhan isolat bakteri XJ20 ( $\bullet$ ) dalam media cair xilan $0.5 \%$ 
Suhu dan pH Optimum Xilanase serta Stabilitasnya. Aktivitas enzim xilanase dari isolat bakteri XJ20 memiliki tiga puncak dengan waktu berbeda (jam ke-6, jam ke-14 dan jam ke-20). Pengujian pengaruh $\mathrm{pH}$ dan suhu dilakukan pada dua puncak tertinggi yakni pada puncak pertama (jam ke-6) dan puncak kedua (jam ke-14).

Hasil pengujian aktivitas enzim pada berbagai suhu menunjukkan bahwa aktivitas enzim pada jam ke-6 dan ke-14 mencapai aktivitas tertingginya pada suhu yang sama, yaitu $70{ }^{\circ} \mathrm{C}$. Namun demikian, aktivitas xilanase pada jam ke-6 tercatat lebih tinggi dibandingkan jam ke-14. Aktivitas xilanase tertinggi pada jam ke-6 adalah $0.032 \mathrm{U} / \mathrm{mL}$ sedangkan pada jam ke-14 adalah $0.028 \mathrm{U} / \mathrm{mL}$ (Gambar 3).

Hasil pengujian aktivitas enzim pada suhu $70^{\circ} \mathrm{C}$ pada berbagai $\mathrm{pH}$ menunjukkan aktivitas enzim xilanase pada jam ke-6 dan ke-14 masing-masing mencapai aktivitas tertinggi pada $\mathrm{pH} 4.0(0.046 \mathrm{U} / \mathrm{mL})$ dan $\mathrm{pH}$ $7.0(0.028 \mathrm{U} / \mathrm{mL})($ Gambar 4).

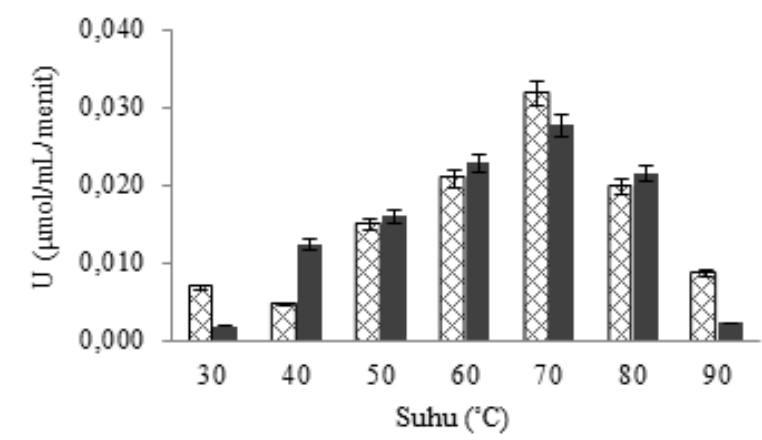

Gambar 3 Aktivitas enzim xilanase isolat bakteri XJ20 pada jam ke-6 (因) dan jam ke-14 ( $\mathbf{0}$ ) dalam media cair xilan $0.5 \%$ pada $\mathrm{pH} 7$ yang diinkubasi pada berbagai suhu.

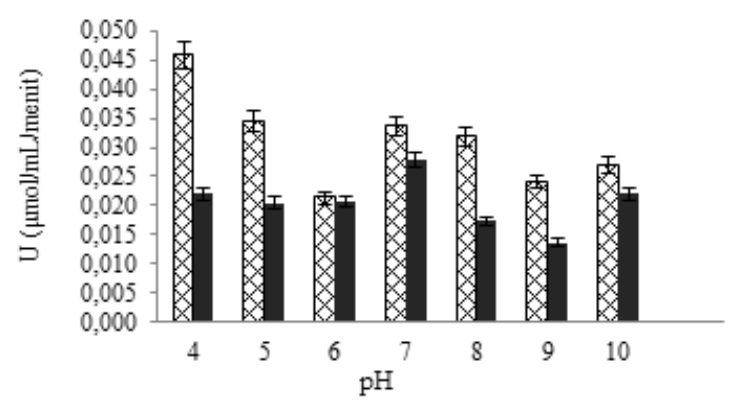

Gambar 4 Aktivitas enzim xilanase isolat XJ20 pada jam ke-6 (因) dan jam ke-14 ( ) dalam media cair xilan $0.5 \%$ pada suhu $70^{\circ} \mathrm{C}$ dengan uji berbagai $\mathrm{pH}$.

Hasil uji stabilitas enzim yang memiliki aktivitas tertinggi pada $\mathrm{pH} 4.0$ dan diinkubasi pada suhu ruang menunjukkan adanya peningkatan dari aktivitas enzimatik awal $0.023 \mathrm{U} / \mathrm{mL}$ pada jam ke-0 menjadi $0,033 \mathrm{U} / \mathrm{mL}$ pada jam ke-1. Kemudian, pada jam ke-2 aktivitas enzim mengalami penurunan menjadi $0.028 \mathrm{U} / \mathrm{mL}$ sampai pada jam ke-9 aktivitas enzim mengalami penurunan mencapai $50 \%$ dari aktivitas enzim awal
0,012 U/mL. Aktivitas enzim terus menurun hingga jam ke-12 (Gambar 5).

Aktivitas enzim yang diinkubasi pada suhu 70 ${ }^{\circ} \mathrm{C}$ menunjukkan hasil yang sedikit berbeda, dimana aktivitas enzim mengalami penurunan pada jam pertama yakni dari $0.040 \mathrm{U} / \mathrm{mL}$ menjadi $0.037 \mathrm{U} / \mathrm{mL}$, namun aktivitas enzim memperlihatkan peningkatan pada jam ke-3 menjadi $0.039 \mathrm{U} / \mathrm{mL}$. Penurunan aktivitas enzim sebesar $50 \%$ dari aktivitas awalnya terjadi lebih cepat (pada jam ke-6) dibandingkan aktivitas enzim pada suhu ruang (pada jam ke-9). Aktivitas enzim terus mengalami penurunan hingga jam ke-12 (Gambar 5).

Stabilitas enzim yang memiliki aktivitas tertinggi pada pH 7.0 diinkubasi pada suhu ruang menunjukkan adanya penurunan. Pada jam ke-0 aktivitas enzim mencapai $0.026 \mathrm{U} / \mathrm{mL}$ dan menurun hingga lebih dari $50 \%$ menjadi $0.009 \mathrm{U} / \mathrm{mL}$ pada jam ke-4. Aktivitas enzim berhenti pada jam ke-9.

Selain itu, hasil uji stabilitas enzim yang diinkubasi pada suhu $70{ }^{\circ} \mathrm{C}$ menunjukkan adanya peningkatan dari jam ke-0 hingga jam ke-2 yaitu dari $0.010 \mathrm{U} /$ $\mathrm{mL}$ menjadi $0.026 \mathrm{U} / \mathrm{mL}$ dan pada jam ke-3 hingga seterusnya aktivitas enzim mengalami penurunan. Aktivitas enzim menurun hingga 50\% dari aktivitas awal pada jam ke-3 menjadi $0.012 \mathrm{U} / \mathrm{mL}$. Aktivitas enzim berhenti pada jam ke-9 (Gambar 6).

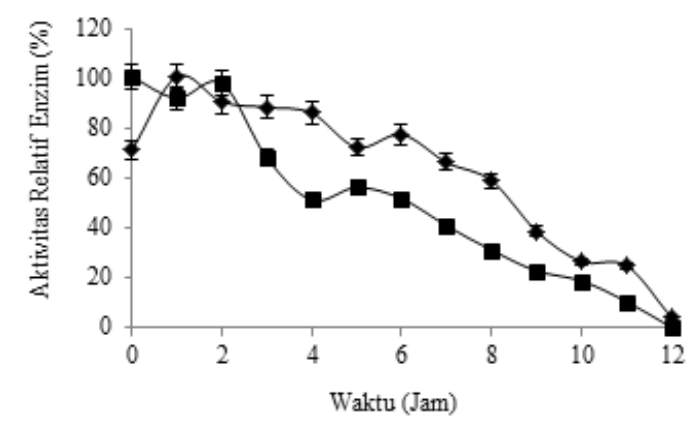

Gambar 5 Stabilitas enzim xilanase isolat XJ20 pada suhu ruang (•) dan $70{ }^{\circ} \mathrm{C}(\boldsymbol{\bullet})$ pada media xilan $0.5 \%$ dengan $\mathrm{pH} 4.0$

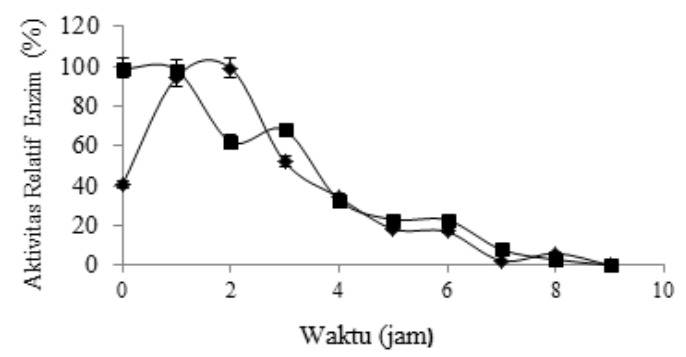

Gambar 6 Stabilitas enzim xilanase isolat XJ20 pada suhu ruang ( ) dan $70{ }^{\circ} \mathrm{C}(\bullet)$ pada media xilan $0.5 \%$ dengan $\mathrm{pH} 7.0$ 


\section{PEMBAHASAN}

Isolat bekteri xilanolitik XJ20 merupakan bakteri Gram positif berbentuk kokus. Beberapa bakteri Gram positif yang telah diketahui dapat menghasilkan xilanase yaitu Bacillus, Cellulomonas, Micrococcus dan Staphylococcus (Gandarillas et al. 2012). Kurrataa'yun et al. (2014) juga melaporkan bahwa bakteri dari genus Paenibacillus yang diisolasi dari tanah mampu menghasilkan xilanase.

Selain bakteri, beberapa genus cendawan juga mampu menghasilkan xilanase. Cendawan Aspergillus fumigatus dan A. niger diketahui mampu menghasilkan xilanase yang tahan atau toleran $\mathrm{pH}$ tinggi (Anthony et al. 2003, Mulyani et al. 2009). Umumnya enzim yang dihasilkan oleh golongan bakteri memiliki ketahanan pada suhu yang lebih tinggi dibanding cendawan, namun aktivitas xilanase dari golongan cendawan jauh lebih tinggi dari bakteri (Bergquist et al. 2002). Penelitian yang telah dilakukan oleh Yamaura et al. (1997) menyebutkan bahwa moluska (hewan lunak) air tawar juga mampu menghasilkan xilanase.

Penentuan waktu produksi enzim xilanase tertinggi dapat dilihat dari aktivitas xilanase tertinggi. Satu unit aktivitas xilanase didefinisikan sebagai banyaknya enzim yang dapat memproduksi $1 \mu \mathrm{mol}$ xilosa per milliliter $(\mathrm{mL})$ dalam 1 menit. Xilanase tergolong sebagai metabolit primer karena dibutuhkan dalam pemecahan sumber karbon xilan yang terdapat pada substrat. Sumber karbon sangat penting dan dibutuhkan dalam pertumbuhan bakteri. Hal tersebut menyebabkan bakteri memproduksi xilanase lebih banyak pada saat fase eksponensial karena pada fase tersebut pertumbuhan yang sangat cepat dari bakteri sedang terjadi. Kondisi pertumbuhan mikroorganisme berhubungan erat dengan aktivitas enzim. Aktivitas enzim dipengaruhi oleh beberapa faktor antara lain $\mathrm{pH}$, suhu, konsentrasi sumber karbon, dan konsentrasi enzim (Li et al. 2011, Sharma dan Chand 2012).

Isolat bakteri XJ20 memiliki 3 puncak aktivitas xilanase. Puncak pertama merupakan puncak tertinggi dicapai pada jam ke-6, saat bakteri memasuki fase eksponensial, sedangkan puncak kedua pada jam ke-14 dan puncak ketiga pada jam ke-20 terjadi saat bakteri berada pada fase stasioner. Terdapatnya tiga puncak aktivitas enzim tersebut diduga karena adanya dua atau lebih jenis enzim yang berbeda. Selain itu, keberadaan isoenzim juga dapat menyebabkan kemunculan puncak aktivitas enzim lebih dari satu (Wilkinson 1967). Penelitian yang telah dilakukan oleh Ahlgren et al. (1967) juga menyebutkan bahwa adanya dua puncak aktivitas enzim menunjukkan adanya dua jenis enzim xilanase yang berbeda, namun hal tersebut juga dapat disebabkan oleh adanya polisakarida (kompleks protein) dalam media. Raghukumara et al. (2004) juga menyatakan bahwa xilanase yang diisolasi dari fungi laut memiliki dua puncak yang diketahui sebagai dua enzim yang berbeda yaitu $\beta$-xilosidase dan $\alpha$-L-arabinofuranosidase.

Penurunan produksi enzim xilanase ditunjukkan oleh menurunnya aktivitas enzim yang ditandai dengan menurunnya grafik aktivitas enzim. Hal tersebut dapat disebabkan oleh beberapa faktor diantaranya feedback inhibition, menurunnya jumlah substrat dan adanya aktivitas proteolisis (White 1995). Xilanase merupakan enzim ekstraseluler yang dihasilkan oleh bakteri untuk menghidrolisis xilan (polisakarida) yang terdapat pada media menjadi molekul gula sederhana yang akan dimetabolisme di dalam sel. Oleh karena itu substrat xilan yang terkandung pada media berpengaruh terhadap aktivitas dan produktivitas enzim xilanase (Susilowati et al. 2012).

Faktor penting lainnya yang harus diperhatikan dalam menentukan waktu optimum aktivitas enzim adalah aerasi. Aerasi juga dapat mempengaruhi pertumbuhan bakteri. Aerasi berfungsi untuk mempertahankan kondisi aerobik dan mengatur temperatur substrat tetap konstan dan stabil. Kondisi aerobik dapat dipertahankan dengan mengatur tingkat oksigen yang dibutuhkan untuk sintesis produk, mengatur tingkat atau kadar $\mathrm{CO}_{2}$ dan tingkat ruang udara yang tersedia didalam substrat (Richana et al. 2000).

Produksi dan kerja enzim dapat dipengaruhi oleh $\mathrm{pH}$, suhu, kecepatan aerasi dan konsentrasi substrat. Penentuan $\mathrm{pH}$ dan suhu optimum sangat penting dilakukan untuk pertumbuhan mikroorganisme dan produksi metabolitnya. Aktivitas optimum enzim berkisar pada $\mathrm{pH}$ dan suhu pertumbuhan mikroorganisme penghasil enzim tersebut (Lloyd dan Nelson 1984). Tingkat $\mathrm{pH}$ akan mempengaruhi konformasi enzim. Konformasi suatu enzim berkaitan dengan kemampuan enzim mengikat atau bereaksi dengan substrat. Jika jumlah substrat yang bereaksi dengan enzim tinggi maka produk yang dihasilkan akan lebih banyak. Suhu juga berpengaruh terhadap aktivitas enzim, karena suhu secara langsung berpengaruh terhadap kecepatan pertumbuhan mikroorganisme, kecepatan sintesis enzim dan kecepatan inaktivasi enzim (Richana et al. 2000).

Pengaruh suhu terhadap aktivitas enzim berkaitan dengan energi kinetik atau pergerakan suatu molekul yang menyatakan semakin tinggi suhu, kecepatan tumbukan molekul juga semakin besar sehingga 
energi untuk reaksi semakin besar dan aktivitas enzim akan semakin tinggi. Namun, suhu tinggi juga dibatasi oleh sifat enzim sebagai protein yang dapat rusak atau terdenaturasi pada suhu tinggi (Eisenthal et al. 2006).

Hasil uji pengaruh $\mathrm{pH}$ dan suhu terhadap aktivitas enzim menunjukkan bahwa puncak pertama dan puncak kedua aktivitas optimum enzim memiliki suhu optimum yang sama, yaitu $70{ }^{\circ} \mathrm{C}$, namun aktivitas xilanase pada puncak pertama lebih tinggi dibandingkan puncak kedua. Berbeda halnya dengan $\mathrm{pH}$, puncak pertama dan puncak kedua aktivitas optimum enzim memiliki pH optimum yang berbeda. Puncak pertama aktivitas optimum enzim memiliki $\mathrm{pH}$ optimum 4.0 sedangkan puncak kedua memiliki $\mathrm{pH}$ optimum 7.0. Perbedaan karakteristik $\mathrm{pH}$ optimum enzim tersebut diduga isolat XJ20 mampu menghasilkan xilanase yang berbeda. Penelitian sebelumnya yang dilakukan oleh Raghukumara et al. (2004) menjelaskan bahwa ditemukan xilanase yang memiliki aktivitas tertinggi pada suhu $50{ }^{\circ} \mathrm{C}$ dan $90{ }^{\circ} \mathrm{C}$ dan diketahui sebagai dua enzim yang berbeda ( $\beta$-xilosidase dan $\alpha$-L-arabinofuranosidase) serta keduanya bekerja sama secara sinergis dalam mendegradasi xilan.

Tinggi rendahnya aktivitas enzim juga dipengaruhi oleh kemampuan bakteri dalam beradaptasi pada kondisi berbagai $\mathrm{pH}$ dan suhu yang berbeda-beda. Habitat yang kurang sesuai menyebabkan bakteri harus beradaptasi terlebih dahulu, hal tersebut dapat menyebabkan bakteri mengeluarkan metabolitnya dalam jumlah sedikit (Said 1987). Aktivitas xilanase juga dipengaruhi oleh jenis bufer yang digunakan. Bufer yang berbeda memiliki nilai $\mathrm{pK}$, jenis dan jumlah muatan ion komponen yang berbeda (Suhartono 1989).

Tujuan dari dilakukannya uji stabilitas enzim adalah mengetahui daya tahan enzim selama penyimpanan setelah proses produksi enzim (Novita et al. 2006). Stabilitas enzim xilanase isolat XJ20 mengalami penurunan dikedua suhu (suhu ruang dan suhu $70^{\circ} \mathrm{C}$. Namun, penurunan aktivitas enzim lebih cepat pada $\mathrm{pH} 7.0$ dibandingkan pada $\mathrm{pH}$ 4.0. Hal ini berkaitan dengan perubahan konformasi enzim selama masa penyimpanan. Kesetabilan suatu enzim dapat dilihat dari tinggi rendahnya aktivitas enzim selama masa penyimpanan. Waktu paruh merupakan waktu aktivitas enzim menurun hingga 50\% dari aktivitas optimumnya. Waktu paruh dapat diketahui dengan melihat aktivitas relatif enzim (Nabilasani dan Sumardi 2015). Waktu paruh enzim xilanase isolat XJ20 yang diinkubasi pada $\mathrm{pH} 7.0$ dan $\mathrm{pH} 4.0$ berbeda. Waktu paruh xilanase pada $\mathrm{pH} 7.0$ lebih cepat dibandingkan pada $\mathrm{pH}$ 4.0. Aktivitas xilanase pada pH 4.0 menurun hingga 50\% sekitar jam ke-6, sedangkan pada $\mathrm{pH} 7.0$ aktivitas enzim menurun hingga 50\% sekitar jam ke-4.

Stabilitas enzim juga dipengaruhi oleh suhu. Penyimpanan enzim pada suhu $70{ }^{\circ} \mathrm{C}$ menyebabkan konformasi enzim lebih cepat berubah dibandingkan dengan penyimpanan pada suhu ruang. Enzim tidak dapat menjaga stabilitasnya lebih lama pada suhu $70{ }^{\circ} \mathrm{C}$ dibandingkan suhu ruang. Waktu paruh enzim pada suhu $70^{\circ} \mathrm{C}$ lebih cepat dibandingkan pada suhu ruang. Kestabilan ataupun aktivitas enzim juga dapat dipengaruhi oleh beberapa kation divalen, seperti $\mathrm{Mn}^{2+}$ (Meryandini et al. 2008).

Simpulan hasil penelitian yang diperoleh yaitu isolat bakteri xilanolitik XJ20 diduga mampu menghasilkan lebih dari satu jenis enzim xilanase. Xilanase yang dihasilkan memiliki suhu optimum $70{ }^{\circ} \mathrm{C}$ dan dua jenis $\mathrm{pH}$ optimum yaitu $\mathrm{pH} 4.0$ dan 7.0. Isolat XJ20 mampu menghasilkan xilanase yang bersifat termofil. Pada $\mathrm{pH} 4.0$ xilanase yang diinkubasi pada suhu ruang dan suhu $70{ }^{\circ} \mathrm{C}$ memiliki waktu paruh berturut-turut 9 jam dan 6 jam, sedangkan pada $\mathrm{pH} 7.04$ jam dan 3 jam. Stabilitas enzim lebih baik pada $\mathrm{pH} 4.0$ dan pada suhu ruang.

\section{DAFTAR PUSTAKA}

Ahlgren E, Eriksson K, Vesterberg O. 1967. Characterization of cellulases and related enzymes by isoelectric focusing, gel filtration and zone electrophoresis. Acta Chem Scand. 21(4):937-944.

Anthony T, Raj KC, Rajendran A, Gunasekaran P. 2003. High molecular weight cellulase-free xylanase from alkali-tolerant Aspergillus fumigatus AR1. Enzyme. Microb. Technol. 32:647-654.

Beg QK, Kapoor M, Mahajan L, Hoondal GS. 2001. Microbial xylanases and their industrial applications: a review. Appl Microbiol Biotechnol. 56:326-338.

Eisenthal R, Peterson ME, Daniel RM, Danson MJ. 2006. The thermal behavior of enzymes : implication for biotechnology. Trends Biotechnol. 24(7):289-292. doi:10.1016/j. tibtech.2006.05.04.

Gandarillas C, Soto R, Vargas VA. 2012. Xylanase production using barley straw by Bacillus sp. LB-4 isolated from laguna Blanca, Potosi-Bolivia. Rev Boliv Quim. 29(1):63-70.

Kulkarni N, Shendye A, Rao M.1999. Molecular and biotechnological aspects of xylanases. Microbiol. 23: 411456.

Kurrataa'yun, Yopi, Meryandini A. 2014. Characterization of xylanase activity produced by Paenibacillus sp. XJ18 from TNBD Jambi, Indonesia. Hayati. 22(1):20-26. doi: 10.4308/ hjb.22.1.20.

Li M, Liao X, Zhang D, Du G, Chen J. 2011. Yeast extract promotes cell growth and induces production of polyvinyl; alcohol-degrading enzymes. Enz Research. 2011(1):1-8. doi: $10.4061 / 2011 / 179819$.

Lloyd NE, Nelson WJ. 1984. Glucose and Fructose Containing Sweeteners from Starch.Chemistry and Technology Academic Press.

Meryandini A, Anggreandari R, Rachmania N. 2008. Isolasi 
bakteri mananolitik dan karakterisasi mananasenya. Biota. 13:82-88

Miller GL. 1959. Use of dinitrosalycilic acid reagent for determination of reducing sugar. Anal Chem. (31):426-428.

Mulyani N S, Asy'ari M, Prasetiyoningsih H. 2009. Penentuan konsentrasi optimum oat spelt xylan pada produksi xilanase dari Aspergillus Niger dalam media PDB (Potato Dextrose Broth). J Kim Sains \& Apl. 12:(1).

Nabilasani GC, Sumardi. 2015. Karakterisasi enzim xilanase dari Bacillus sp. Seminar Nasional Sains dan Teknologi VI Lembaga Penelitian dan Pengabdian Universitas Lampung; 2015 November 3; Bandar Lampung, Indonesia. Lampung (ID): Jurusan Biologi FMIPA Universitas Lampung. 584-595.

Novita W. Arief K. Nisa FC. Murdiyatmo U. 2006. Karakterisasi parsial ekstrak kasar enzim protease dari Bacillus amyloliquefaciens NRRL B-14396. JTP. 7(2):96-105.

Raghukumara C, Muraleedharan U, Gaud VR, Mishra R. 2004. Xylanases of marine fungi of potential use for biobleaching of paper pulp. J Ind Microbiol Biotechnol. 31(9): 433-441. doi:2264.174.

Richana N, Lestari P, Thontowi A, Rosmimik. 2000. Seleksi isolat bakteri lokal penghasil xilanase. J Microbiol Indo. $5(2): 54-56$.

Richana N. 2002. Produksi dan prospek enzim xilanase dalam pengembangan bioindustri di Indonesia. Buletin Agrobio. (1):29-36.

Said G. 1987. Biondustri: Penerapan Teknologi Fermentasi. Bogor (ID): PAU IPB.

Samsuri M, Gozan M, Wijanarko, Hermansyah H, Wulan PPDK, Dianursanti, Nasikin M, Prasetya B. 2009. Hydrolisys of bagas by cellulose and xylanase for bioethanol production in simultaneous saccharification and fermentation. $J$ Applied
Indust Biotechnol. 2(2):1979- 9784.

Sharma PK, Chand D. 2012. Production of cellulose-free thermostable xylanase from Pseudomonas sp.XPB-6. $J$ Biological Sci.1(5):31-41.

Subramaniyan S, Prema P. 2002. Critical Rev. Biotechnol. 22(1):33-46.

Suhartono MT. 1989. Pengantar Biokimia. Bogor(ID): PAU IPB. Susilowati PE, Raharjo S, Kurniawati D, Rahim R, Sumarlin, Ardiansyah. 2012. Produksi xilanase dari isolate sumber air panas Sonai, Sulawesi Tenggara menggunakan limbah pertanian. J Natur Indonesia. 14(3): 199-204.

Trismilah, Waltam DR. 2009. Produksi Xilanase Menggunakan Media Limbah Pertanian dan Perkebunan. J Tek Ling. 10(2): 137-144.

Viikari. 2001. Xylanases in bleaching from an idea to the industry. FEMS Microbiol. Rev 13: 335-350.

Wang J, Zhang W, Liu J, Cao Y, Bai X, Gong Y, Cen P, Yang M. 2010. An alkali-tolerant xylanase produced by the newly isolated alkaliphitic Bacillus pumilus from paper mill effluent. Mol Bio Rep. 37:3297-3302.

White D. 1995. The Physiology and Biochemistry of Prokaryotes. New York(US): Oxford University Press.

Wilkinson JH. 1967. Isoenzymes. Mol Nut Food Res. 11(4):385386. doi: 10.1002/food.19670110418.

Yamaura I, Koga T, Matsumoto T, Kato T. 1997. Purification Some Properties of Endo-1,4- $\beta$-D-xylanase from a Freshwater Mollusc, Pomacea insularus (de Ordigny). Biosci. Biotech. Biochem. 61(4): 615-620.

Yang W, Ajapur VK, Krishnamurthy K, Feng H, Yang R, Rababah TM. 2009. Expedited extraction of xylan from corncob by powder ultrasound. Int J Agric \& Biol Eng. 2(4):76-83. 